Terr. Atmos. Ocean. Sci., Vol. 17, No. 4, 903-920, December 2006

\title{
Extremely High Methane Concentration in Bottom Water and Cored Sediments from Offshore Southwestern Taiwan
}

\author{
Pei-Chuan Chuang ${ }^{1}$, Tsanyao Frank Yang ${ }^{1,}{ }^{*}$, Saulwood Lin ${ }^{2}$, Hsiao-Fen Lee ${ }^{1}$, Tefang F. Lan ${ }^{1}$, \\ Wei-Li Hong ${ }^{1}$, Char-Shine Liu ${ }^{2}$, Ju-Chin Chen ${ }^{2}$, and Yunshuen Wang ${ }^{3}$
}

(Manuscript received 10 March 2006, in final form 28 September 2006)

\begin{abstract}
It has been found that Bottom Simulating Reflections (BSRs), which infer the existence of potential gas hydrates underneath seafloor sediments, are widely distributed in offshore southwestern Taiwan. Fluids and gases derived from dissociation of gas hydrates, which are typically methane enriched, affect the composition of seawater and sediments near venting areas. Hence, methane concentration of seawater and sediments become useful proxies for exploration of potential gas hydrates in a given area. We systematically collected bottom waters and sedimentary core samples for dissolved and pore-space gas analyses through five cruises: ORI-697, ORI-718, ORII-1207, ORII-1230, and ORI-732 from 2003 to 2005 in this study. Some sites with extremely high methane concentrations have been found in offshore southwestern Taiwan, e.g., sites G23 of ORI-697, N8 of ORI-718, and G96 of ORI-732. The methane concentrations of cored sediments display an increasing trend with depth. Furthermore, the down-core profiles of methane and sulfate reveal very shallow depths of sulfate methane interface (SMI) at some sites in this study. It implies sulfate reduction being mainly driven by the process of anaerobic methane oxidation (AMO) in sediments; thus indicating that there is a methane-enriched venting source, which may be the product of dissociation of gas hydrates in this area.
\end{abstract}

(Key words: Methane, Gas hydrate, Sulfate methane interface, Anaerobic methane oxidation)

\footnotetext{
${ }^{1}$ Department of Geosciences, National Taiwan University, Taipei, Taiwan, ROC

2 Institute of Oceanography, National Taiwan University, Taipei, Taiwan, ROC

${ }^{3}$ Central Geological Survey, MOEA, Taipei, Taiwan, ROC

* Corresponding author address: Prof. Tsanyao Frank Yang, Department of Geosciences, National Taiwan University, Taipei, Taiwan, ROC; E-mail: tyyang@ntu.edu.tw
} 


\section{INTRODUCTION}

Gas hydrates, which are a kind of non-stoichiometric clathrate, are natural occurring solids composed of water molecules forming a rigid lattice of cages with most of the cages each containing a molecule of natural gas, mainly methane. These are metastable crystal products at low temperature and high-pressure. If the temperature and pressure conditions are above the gas hydrate stability boundary, then the protogenic gas hydrates dissociate into water and methane. Gas hydrates are widely distributed in the permafrost of polar regions and the strata of continental deep-sea areas (Kvenvolden 1998; Pellenbarg and Max 2000; Sloan 1998; Milkov 2004) and are considered future potential energy resources.

There are conditions under which gas hydrates beneath the ocean floor may become unstable: firstly, if there is a general change in temperature and pressure conditions at the seafloor; and secondly, if warm fluids begin moving through highly permeable faults (Pecher 2002). When dissociation occurs, the frozen sediments become liquefied releasing water and dissociated gases and thereby increasing pore pressure. These high-pressure fluids from gas hydrate dissociation permeate upward through the seafloor. Here, there is a strong potential for faults and porous layers to provide the main migration pathways for fluids in gas hydrate bearing layers (Pecher 2002; Wood et al. 2002).

The fluids dissociated from gas hydrates may erupt through craters forming mud volcanoes. This may explain the presence of submarine mud volcanoes in offshore southwestern Taiwan (e.g., Chou et al. 2000; Chiu et al. 2006), which have been considered to be related to on-land mud volcanoes (Yang et al. 2003, 2004) by Yeh (2003). Moreover, these methane-rich fluids influence the composition of pore water and bottom seawater around these gas-expelling craters.

Local scientists have done many geophysical investigations on gas hydrates in offshore southwestern Taiwan. Based on seismic reflection profiles, they found many Bottom Simulating Reflections (BSRs) and concluded that gas hydrates are widely distributed under the seafloor of depths of 700 to $3000 \mathrm{~m}$ in this region (Chi et al. 1998; Chow et al. 2000; Schnürle et al. 1999, 2002, 2006; Liu et al. 2006). The study presents the first systematic survey based on gas geochemical techniques performed in the gas hydrate area in offshore SW Taiwan. We collected bottom waters and cored sediments for fluid and gas geochemistry study during five cruises (ORI-697; ORI-718; ORI-732; ORII-1207; ORII-1230) from 2003 to 2005. The sampling sites are shown in Fig. 1.

In comparison with gas hydrate studies in other areas (Kvenvolden and Lorenson 2000; Lorenson and Collett 2000), our results show unusually high methane concentration in bottom water and sediment pore space. This phenomenon can be explained by venting methane, which could be due to the release of methane from gas hydrate dissociation migrating upward.

\section{ANALYTICAL METHODS AND PROCEDURES}

Bottom water and sediment samples were collected for analyzing dissolved methane concentration in seawater and pore spaces. Sediment samples were collected by both gravity $(30-100 \mathrm{~cm}$ of length) and piston (300 - $500 \mathrm{~cm}$ of length) core samplers. Bottom seawater samples are 

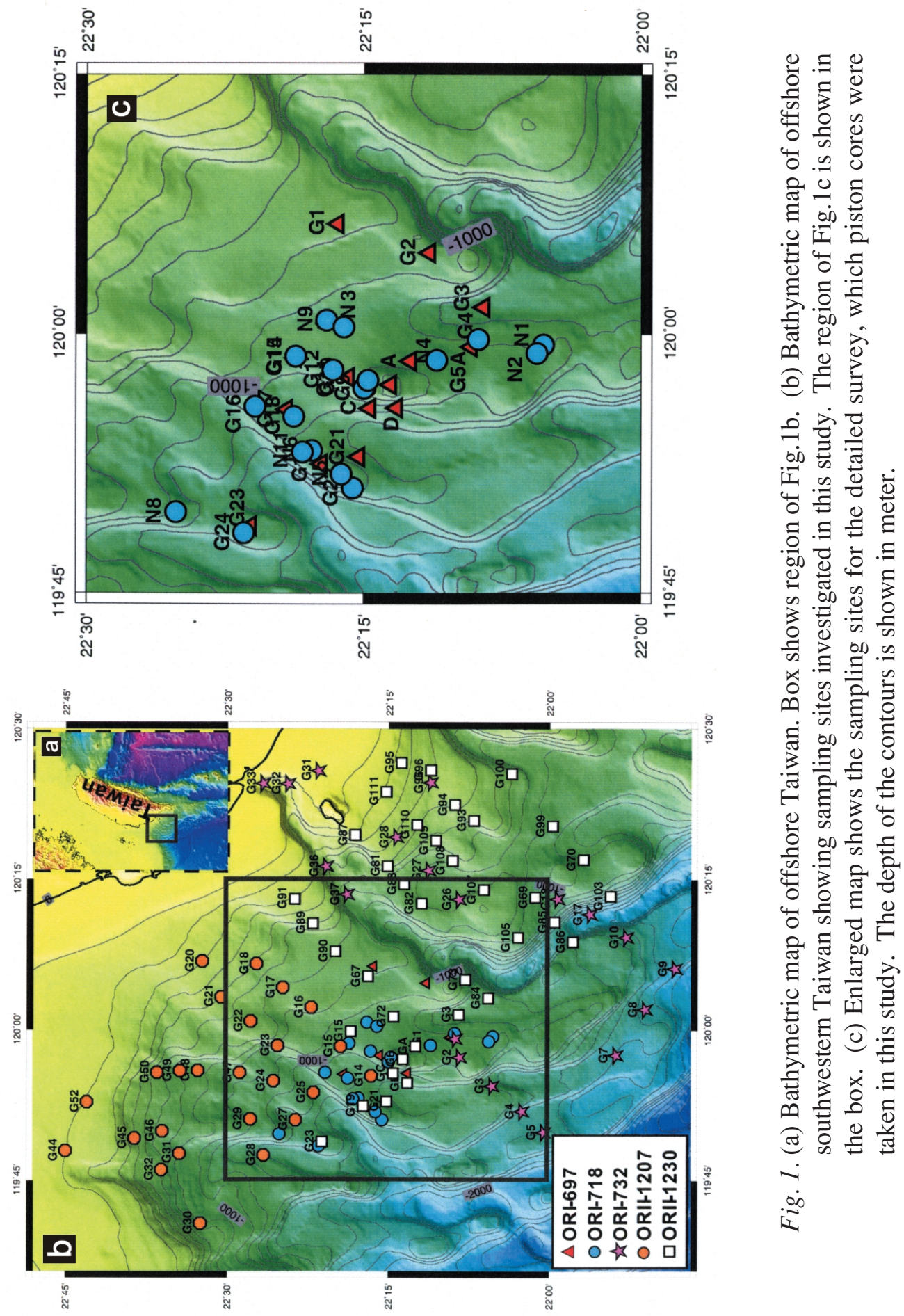
represented by core top waters. The core top waters were collected in plastic bottles and then transferred immediately to low permeability glass bottles. After being given an ultrasonic bath at $60^{\circ} \mathrm{C}$ for 10 minutes, the dissolved gas of the bottom water was transferred to a $7-\mathrm{ml}$ Vacutainer using a gas tight syringe. The extracted gases were analyzed using gas chromatography.

Sediments were placed in a tin can of volume ca. $930 \mathrm{~cm}^{3}$ immediately after the cores were retrieved on board. Distilled water was added into the can and a fixed space remained as the headspace. $\mathrm{HgCl}_{2}$ was added as a bacterial inhibitor. To avoid water and gas escaping, the cover was sealed by silicone gel. After the silicone dried, the can was kept upside down and ready for analyses.

In order to release all gases into the headspace from the pore space of the sediments, the tin can was first shaken after being brought back to a shore-based laboratory and then kept at room temperature for 30 minutes. A gas-tight syringe's needle, connected to a Vacutainer, was allowed to pierce the tinplate can using a septa. Gases from the headspace were thus transferred to the Vacutainer. These extracted gases were then injected into a gas chromatograph for analysis.

Gas was introduced into a gas chromatograph (GC) (SRI 8610C) equipped with both thermal conductivity (TCD) and flame ionization (FID) detectors. Different components of the gas were separated in GC (injection temperature $30^{\circ} \mathrm{C}$, held isothermal for 2 minutes, ramped to $250^{\circ} \mathrm{C}$ at $120^{\circ} \mathrm{C} \mathrm{min}^{-1}$ ). The system utilized two carrier gases, hydrogen and argon. Hydrogen was supplied by a hydrogen generator for use in the FID and in one TCD; whilst the other TCD utilized argon supplied by a cylinder tank. In general, most gas components analyzed in this system have analytical errors of less than $5 \%$ with low detection and quantification limits (Lee et al. 2005). Results of dissolved methane concentrations are reported relative to the volume of seawater from which the gases were extracted (i.e., nanoliters of gas per liter of seawater $\left.\left[\mathrm{nL} \mathrm{L}^{-1}\right]\right)$ and methane concentrations of cored sediments are reported relative to wet sediment from which the gases were extracted (i.e., microliters of gas per liter of wet sediment $\left.\left[\mu \mathrm{L} \mathrm{L}^{-1}\right]\right)$.

\section{RESULTS}

\subsection{Dissolved Methane Concentrations in Bottom Water}

Results obtained from core top waters of 114 sites are listed in Table 1. Most of the samples contain methane as the dominant hydrocarbon gas. Most $\mathrm{C}_{2+}$ gases are below detection limits, so only the results of methane concentration are given here. The results can be arbitrarily divided into five groups: (a) Very low methane concentration (below detection limits); (b) Low methane concentration $\left(<100 \mathrm{~nL} \mathrm{~L}^{-1}\right)$; (c) High methane concentration (100 $\left.\sim 1000 \mathrm{~nL} \mathrm{~L}^{-1}\right)$; (d) Very high methane concentration $\left(1000 \sim 10000 \mathrm{~nL} \mathrm{~L}^{-1}\right)$; (e) Especial high methane concentration $\left(10000 \sim 100000 \mathrm{~nL} \mathrm{~L}^{-1}\right)$; (f) Extremely high methane concentration ( $>100000 \mathrm{~nL} \mathrm{~L}^{-1}$ ). The concentration distribution of the dissolved methane in bottom water in this study is compiled in Fig. 2. It shows that most sites exhibit much higher dissolved methane concentration than those in normal seawater, which is usually below $50 \mathrm{~nL} \mathrm{~L}^{-1}$ (Millero 1996). 
Table 1. Dissolved methane concentrations measured in Offshore Southwestern Taiwan bottom seawaters.

\begin{tabular}{|c|c|c|c|c|c|c|c|c|c|}
\hline $\begin{array}{l}\text { ORI-697 } \\
\text { Cruise }\end{array}$ & $\begin{array}{r}\mathrm{CH}_{4} \\
(\mathrm{~nL} / \mathrm{L})\end{array}$ & $\begin{array}{l}\text { ORI-718 } \\
\text { Cruise }\end{array}$ & $\begin{array}{c}\mathrm{CH}_{4} \\
(\mathrm{~nL} / \mathrm{L})\end{array}$ & $\begin{array}{l}\text { ORII-1207 } \\
\text { Cruise }\end{array}$ & $\mathrm{CH}_{4}(\mathrm{~nL} / \mathrm{L})$ & $\begin{array}{l}\text { ORII-1230 } \\
\text { Cruise }\end{array}$ & $\mathrm{CH}_{4}(\mathrm{~nL} / \mathrm{L})$ & $\begin{array}{l}\text { ORI-732 } \\
\text { Cruise }\end{array}$ & $\begin{array}{r}\mathrm{CH}_{4} \\
(\mathrm{~nL} / \mathrm{L})\end{array}$ \\
\hline G1 & 282 & G4 & 3,740 & G-15 & 384 & A & 19,732 & G1 & 5,365 \\
\hline G5A & 212 & G9 & 4,970 & G-16 & 441 & $\mathrm{D}$ & 4,897 & G2 & 3,473 \\
\hline G6 & 148 & G11 & 3,638 & G-18 & 792 & G3 & 21,239 & G3 & 45,797 \\
\hline G10 & 156 & G11C & 822 & G-20 & 516 & G6 & 27.9 & G4 & 5,494 \\
\hline G15 & 156 & G12 & 557 & G-22 & 876 & G15 & 43,318 & G5 & 81,490 \\
\hline G17 & 1,221 & G14 & 10,838 & G-24 & 723 & G19 & 7,221 & G7 & 8,667 \\
\hline G19 & 390 & G16 & 762 & G-27 & 749 & G21 & 53,888 & G8 & 6,230 \\
\hline G21 & 613 & G18 & 2,368 & G-28 & 809 & G23 & 2,912 & G9 & 64,117 \\
\hline \multirow[t]{25}{*}{ G23 } & 198,616 & G22 & 78,731 & G-29 & 326 & G67 & 1,247 & G10 & 13,364 \\
\hline & & G24 & 935 & G-30 & 458 & G69 & 30,196 & G17 & 53,796 \\
\hline & & N1 & 6,204 & G-32 & 705 & G70 & 17,510 & G18 & 21,472 \\
\hline & & $\mathrm{N} 2$ & 9,750 & G-44 & 308 & G73 & 11,035 & G26 & 140 \\
\hline & & N4 & 3,793 & G-45 & 416 & G81 & 41,298 & G27 & 44,743 \\
\hline & & N5 & 4,543 & G-47 & 329 & G82 & 65,153 & G28 & 13,194 \\
\hline & & N6 & 2,450 & G-48 & 477 & G84 & 4,120 & G31 & 4,186 \\
\hline & & N8 & 613,268 & G-50 & 597 & G85 & 135 & G32 & 274 \\
\hline & & N9 & 12,702 & & & G86 & 2,666 & G33 & 8,751 \\
\hline & & N11 & 10,544 & & & G87 & 20,633 & G36 & 141 \\
\hline & & & & & & G89 & 58,259 & G37 & 20,718 \\
\hline & & & & & & G90 & 99.6 & G96 & 536,323 \\
\hline & & & & & & G91 & 44,383 & & \\
\hline & & & & & & G93 & 8,392 & & \\
\hline & & & & & & G94 & 11,120 & & \\
\hline & & & & & & G95 & 36,844 & & \\
\hline & & & & & & G96 & 47,551 & & \\
\hline & & & & & & G99 & 18,732 & & \\
\hline & & & & & & G100 & 25,566 & & \\
\hline & & & & & & G103 & 2,201 & & \\
\hline & & & & & & G105 & 988 & & \\
\hline & & & & & & G107 & 7,453 & & \\
\hline & & & & & & G108 & 38,559 & & \\
\hline & & & & & & G109 & 475 & & \\
\hline & & & & & & G110 & 23,921 & & \\
\hline
\end{tabular}




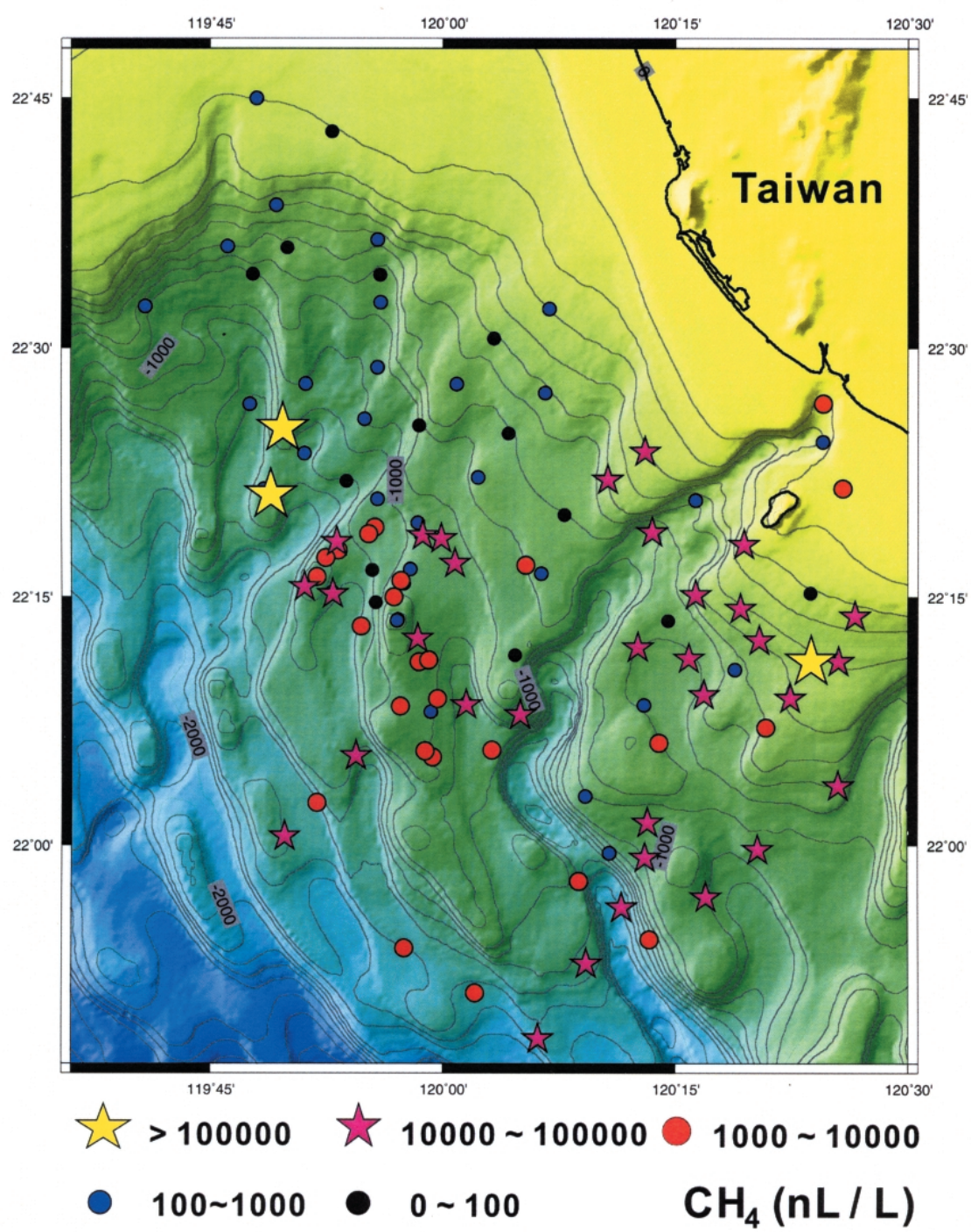

Fig. 2. Map of methane concentrations (in $\mathrm{nL} \mathrm{L}^{-1}$ ) in bottom seawaters distributed in offshore southern Taiwan.

\subsection{Methane and Ethane Concentrations of Cored Sediments}

Methane is the main component of hydrocarbon gases, ethane is the minor component and $\mathrm{C}_{3+}$ gases usually are below detection limits. The results are consistent with recent work of Oung et al. (2006) in this area. Table 2 shows both methane and ethane concentrations of all 
cored samples of each cruise. Note that the reported concentrations are considered to be the minimum values of the samples due to possible gas loss during core recovery, cutting, sample storage and gas transfer before analysis.

Except for a few sites, e.g., sites GD of ORI-697 and G24 of ORI-718 where the methane concentrations are very low (less than $10 \mu \mathrm{L} \mathrm{L}^{-1}$ ), the results show that most of the methane concentrations in the pore spaces range from $\sim 10$ to $\sim 10000 \mu \mathrm{L} \mathrm{L}^{-1}$.

In general, most of the cored samples show less methane concentrations in the shallower depths, and methane concentration increasing with increasing depth (Fig. 3; see Table 2 for details). Extremely high methane concentrations can be found at some sites, especially sites G23 of ORI-697, G22, N8 of ORI-718, and G96 of ORI-732 cruises. In contrast, methane concentrations at some sites do not change much with depth and maintain similar values $\left(10^{2} \sim 10^{3} \mu \mathrm{L} \mathrm{L}^{-1}\right)$ (Fig. 3), e.g., sites: G1, G3, G6, GA of ORI-697, and N4, N13, G4, G14 of ORI-718. It is worth noting that methane profiles at some sites show a saw-tooth shape, e.g., sites G19 of ORI-697 and N11, N9 of ORI-718, which indicate possible gas leaks at some depths or multiple gas sources underneath some sites.

Note that the gravity core samples, of three cruises, ORII-1207, ORII-1230 (except G96) and ORI-732 (except G96), show low methane concentrations $\left(<10^{3} \mu \mathrm{L} \mathrm{L}^{-1}\right)$ at all sites. The length of cored sediments from gravity core samplers usually is less than $2 \mathrm{~m}$, so the change of methane concentrations with depth is unknown for those sites.

\section{DISCUSSIONS}

\subsection{Very Shallow Depth of Sulfate Methane Interface}

Sulfate is involved in two chemical reactions induced by microbial activity that deplete sulfate in pore waters of the sulfate reduction zone within anoxic marine sediments. In the first process, sulfate, which is a kind of oxidant, reacts with sedimentary organic matter. The net reaction of the first process is shown as equation (1):

$$
2\left(\mathrm{CH}_{2} \mathrm{O}\right)+\mathrm{SO}_{4}^{2-} \rightarrow 2 \mathrm{HCO}_{3}^{-}+\mathrm{H}_{2} \mathrm{~S} \text {. }
$$

In the second process, sulfate reacts with methane called anaerobic methane oxidation (AMO). The net reaction of the second process can be shown as equation (2):

$$
\mathrm{CH}_{4}+\mathrm{SO}_{4}^{2-} \rightarrow \mathrm{HCO}_{3}^{-}+\mathrm{HS}^{-}+\mathrm{H}_{2} \mathrm{O} \text {. }
$$

By combining the profiles of interstitial sulfate concentration and the methane concentration of pore spaces in sediments from a gas hydrate area, it is typical to observe sulfate depleting and methane increasing dramatically at a particular depth; this is called the Sulfate Methane Interface (SMI). If methane fluxes from sediments are high, sulfate reduction rates will be fast. Furthermore, fast sulfate reduction rates induce shallower depth of the SMI. Therefore, the profiles of interstitial sulfate concentration and the methane concentration of pore space in sediments can provide an indicator for further estimation of methane fluxes from buried sediments if there are gas hydrates beneath the sea floor (Borowski et al. 1996, 1999). 
Table 2. Methane and ethane concentrations of cored samples in this study.

\begin{tabular}{|c|c|c|c|c|c|c|c|c|c|c|c|}
\hline $\begin{array}{l}\text { ORI-697 } \\
\text { cruise }\end{array}$ & $\begin{array}{l}\mathrm{CH}_{4} \\
(\mu \mathrm{L} / \mathrm{L})\end{array}$ & $\begin{array}{l}\mathrm{C}_{2} \mathrm{H}_{6} \\
(\mu \mathrm{L} / \mathrm{L})\end{array}$ & & ORI- 718 cruise & $\begin{array}{l}\mathrm{CH}_{4} \\
(\mu \mathrm{L} / \mathrm{L})\end{array}$ & $\begin{array}{l}\mathrm{C}_{2} \mathrm{H}_{6} \\
(\mu \mathrm{L} / \mathrm{L})\end{array}$ & & ORI-718 cruise & $\begin{array}{l}\mathrm{CH}_{4} \\
(\mu \mathrm{L} / \mathrm{L})\end{array}$ & $\begin{array}{l}\mathrm{C}_{2} \mathrm{H}_{6} \\
(\mu \mathrm{L} / \mathrm{L})\end{array}$ & \\
\hline G1 20-30 & 540 & - & $\mathrm{P}$ & G4 31-40 & 375 & 8.79 & $\mathrm{P}$ & N8 $31-40$ & 117 & 21.6 & $\mathrm{P}$ \\
\hline G1 $120-130$ & 492 & - & & G4 81-90 & 745 & 10.8 & & N8 $81-90$ & 1301 & 8.53 & \\
\hline G1 $220-230$ & 663 & - & & G7 $31-40$ & 595 & 10.6 & $\mathrm{P}$ & N8 $131-140$ & 94,602 & 34.7 & \\
\hline G2 20-30 & 392 & - & $\mathrm{P}$ & G9 $31-40$ & 867 & 8.96 & $\mathrm{P}$ & N8 $181-190$ & 121,716 & 40.5 & \\
\hline G2 $120-130$ & 4,964 & - & & G9 81-90 & 805 & 11.4 & & N9 $31-40$ & 8.75 & 2.76 & $\mathrm{P}$ \\
\hline G3 70-80 & 442 & - & $\mathrm{P}$ & G9 131-140 & 375 & 10.8 & & N9 $81-90$ & 215 & 20.4 & \\
\hline G3 $170-180$ & 294 & - & & G9 181-190 & 395 & 10.8 & & N9 $131-140$ & 37.7 & 14.3 & \\
\hline G3 270-280 & 423 & - & & G9 231-240 & 363 & 8.79 & & N9 $181-190$ & 4.01 & 2.26 & \\
\hline G3 $370-380$ & 759 & 25.4 & & G9 281-290 & 3,668 & 11.7 & & N9 231-240 & 6,457 & 65.1 & \\
\hline G5A $70-80$ & 166 & 2.05 & $\mathrm{P}$ & G11 31-40 & 384 & 8.71 & $\mathrm{P}$ & N9 281-290 & 10.5 & 0.09 & \\
\hline G5A $120-130$ & 192 & - & & G11 79-88 & 1,138 & 30.6 & & N11 31-40 & 7.01 & 5.85 & $\mathrm{P}$ \\
\hline G5A $170-180$ & 215 & - & & G11c $31-40$ & 392 & 8.91 & $\mathrm{P}$ & N11 81-90 & 22.1 & 19.3 & \\
\hline G5A $220-230$ & 626 & 4.08 & & G14 31-40 & - & 2.57 & $\mathrm{P}$ & N11 $131-140$ & 6,722 & 5.96 & \\
\hline G5A $270-280$ & 23,251 & 21.5 & & G14 81-90 & 71.4 & 1.75 & & N11 181-190 & 12.4 & 2.44 & \\
\hline G6 70-80 & 305 & - & $\mathrm{P}$ & G14 131-140 & 246 & 2.54 & & N11 231-240 & 29,261 & 2.66 & \\
\hline G6 120-130 & 328 & 20.4 & & G22 $31-40$ & 35.4 & 9.26 & $\mathrm{P}$ & N11 281-290 & 12.6 & 3.95 & \\
\hline G6 170-180 & 542 & 42.3 & & G22 81-90 & 65.9 & - & & N11 $331-340$ & 12.3 & 0.40 & \\
\hline G6 220-230 & 761 & 47.8 & & G22 131-140 & 310 & 17.9 & & N11 $381-340$ & 11.7 & 0.63 & \\
\hline G10 20-30 & 864 & - & $\mathrm{P}$ & G22 181-190 & 760 & 51.0 & & N13 31-40 & 349 & 8.71 & $\mathrm{P}$ \\
\hline G10 70-80 & 5,283 & - & & G22 231-240 & 1,427 & 4.19 & & N13 81-90 & 366 & 11.3 & \\
\hline G15 20-30 & 283 & - & $\mathrm{P}$ & G22 280-290 & 4,143 & 16.5 & & N13 $131-140$ & 598 & 9.65 & \\
\hline G15 70-80 & 507 & - & & G22 $331-340$ & 61,638 & 47.3 & & N13 181-190 & 434 & 6.94 & \\
\hline G15 $120-130$ & 1,143 & 5.56 & & G22 381-390 & 71,287 & 66.7 & & N13 231-240 & 382 & 10.7 & \\
\hline G15 220-230 & 4,539 & 74.5 & & G22 430-440 & 68,490 & 36.3 & & N13 281-290 & 389 & 11.6 & \\
\hline G15 250-260 & 5,742 & 81.4 & & G24 31-40 & - & 2.35 & $\mathrm{P}$ & N13 331-340 & 473 & 9.33 & \\
\hline G17 20-30 & 5,145 & 3.85 & $\mathrm{P}$ & G24 81-90 & 3.02 & 1.14 & & N13 381-390 & 369 & 9.13 & \\
\hline G17 70-80 & 24,699 & 167 & & G24 131-140 & - & 4.24 & & N13 431-440 & 373 & 9.54 & \\
\hline G19 20-30 & 321 & - & $\mathrm{P}$ & G24 181-190 & 5.31 & 0.50 & & N13 481-490 & 347 & - & \\
\hline G19 70-80 & 179 & - & & G24 231-240 & 4.18 & 0.64 & & N13 531-540 & 376 & 9.91 & \\
\hline G19 120-130 & 2,878 & 26.2 & & G24 281-290 & - & - & & & & & \\
\hline G19 170-180 & 363 & 8.18 & & G24 381-390 & 5.42 & 2.68 & & & & & \\
\hline G21 $70-80$ & 378 & - & $\mathrm{P}$ & $\mathrm{G} 24431-440$ & 0.14 & 0.08 & & & & & \\
\hline G21 $170-180$ & 220 & - & & N1 $31-40$ & 6.54 & 1.42 & $\mathrm{P}$ & & & & \\
\hline G21 $220-230$ & 425 & - & & N1 $81-90$ & 24.5 & 4.14 & & & & & \\
\hline G21 270-280 & 20,703 & - & & N1 131-140 & 74.3 & 1.52 & & & & & \\
\hline G23 20-30 & 515 & 140 & $\mathrm{P}$ & N1 181-190 & 850 & 6.96 & & & & & \\
\hline G23 70-80 & 370 & 244 & & N1 441-445 450-455 & 2,023 & 1.96 & lost $445-450 \mathrm{~cm}$ & & & & \\
\hline G23 120-130 & 117,433 & 109 & & N2 $81-90$ & 7.64 & 3.58 & $\mathrm{P}$ & & & & \\
\hline G23 170-180 & 109,412 & 89.2 & & N2 $131-140$ & 4.17 & 0.83 & & & & & \\
\hline G23 220-230 & 41,038 & 5.34 & & N4 31-40 & 377 & 10.5 & $\mathrm{P}$ & & & & \\
\hline G23 270-280 & 108,190 & - & & N4 81-90 & 380 & 9.84 & & & & & \\
\hline G23 $320-330$ & 133,354 & 28.7 & & N4 131-140 & 372 & - & & & & & \\
\hline G23 370-380 & 113,477 & - & & N4 191-190 & 393 & 8.82 & & & & & \\
\hline G23 $420-430$ & 107,778 & - & & N4 231-240 & 395 & 11.8 & & & & & \\
\hline GA $20-30$ & 330 & - & $P$ & N4 281-290 & 299 & 7.42 & & & & & \\
\hline GA $120-130$ & 297 & - & $\mathrm{P}$ & N4 331-340 & 421 & 10.7 & & & & & \\
\hline GA $220-230$ & 281 & - & & N4 381-390 & 475 & 11.0 & & & & & \\
\hline GC $70-80$ & 512 & - & & N4 431-440 & 518 & 11.3 & & & & & \\
\hline GC $220-230$ & 1,203 & - & & N4 481-490 & 624 & 11.8 & & & & & \\
\hline GC $320-330$ & 3,722 & 46.0 & & N4 531-540 & 938 & 13.0 & & & & & \\
\hline GD $70-80$ & - & 36.1 & $\mathrm{P}$ & N6 31-40 & 9.11 & 0.83 & $\mathrm{P}$ & & & & \\
\hline GD $170-180$ & - & - & & N6 81-90 & 7.56 & 3.73 & & & & & \\
\hline \multirow[t]{7}{*}{ GD $270-280$} & 835 & 8.46 & & N6 131-140 & 7.45 & 4.06 & & & & & \\
\hline & & & & N6 $181-190$ & 24.1 & 0.51 & & & & & \\
\hline & & & & N6 231-240 & 23.9 & 2.90 & & & & & \\
\hline & & & & N6 281-290 & 762 & 4.79 & & & & & \\
\hline & & & & N6 331-340 & 14,651 & 1.05 & & & & & \\
\hline & & & & N6 381-390 & 64,263 & 0.75 & & & & & \\
\hline & & & & N6 431-440 & 74,908 & 0.95 & & & & & \\
\hline
\end{tabular}


Table 2. (Continued)

\begin{tabular}{|c|c|c|c|c|c|c|c|c|c|c|c|}
\hline $\begin{array}{l}\text { ORII-1207 } \\
\text { cruise }\end{array}$ & $\begin{array}{l}\mathrm{CH}_{4} \\
(\mu \mathrm{L} / \mathrm{L}) \\
\end{array}$ & $\begin{array}{l}\mathrm{C}_{2} \mathrm{H}_{6} \\
(\mu \mathrm{L} / \mathrm{L}) \\
\end{array}$ & & $\begin{array}{l}\text { ORII-1230 } \\
\text { cruise }\end{array}$ & $\begin{array}{l}\mathrm{CH}_{4} \\
(\mu \mathrm{L} / \mathrm{L}) \\
\end{array}$ & $\begin{array}{l}\mathrm{C}_{2} \mathrm{H}_{6} \\
(\mu \mathrm{L} / \mathrm{L})\end{array}$ & & $\begin{array}{l}\text { ORI-732 } \\
\text { cruise }\end{array}$ & $\begin{array}{l}\mathrm{CH}_{4} \\
(\mu \mathrm{L} / \mathrm{L})\end{array}$ & $\begin{array}{l}\mathrm{C}_{2} \mathrm{H}_{6} \\
(\mu \mathrm{L} / \mathrm{L}) \\
\end{array}$ & \\
\hline G14 38-48 & 351 & 11.6 & $G$ & GA 40-50 & 241 & 8.79 & $\mathrm{G}$ & G1 40-50 & 256 & 8.32 & $G$ \\
\hline G14 90-100 & 356 & 11.3 & & GA $90-100$ & 235 & 6.66 & & G1 90-100 & 242 & 8.40 & \\
\hline G15 40-50 & 405 & 11.0 & G & GA $140-150$ & 217 & 7.40 & & G3 40-50 & 280 & 8.95 & G \\
\hline G15 90-100 & 520 & 11.7 & & GC $40-50$ & 280 & 6.08 & G & G3 90-100 & 259 & 8.17 & \\
\hline G16 40-50 & 346 & 12.0 & G & GC 90-100 & 387 & 7.20 & & G4 40-50 & 288 & 8.48 & $\mathrm{G}$ \\
\hline G16 90-100 & 360 & 14.1 & & GD $40-50$ & 240 & 7.97 & G & G4 90-100 & 258 & 8.49 & \\
\hline G17 40-50 & 362 & 13.1 & $\mathrm{G}$ & GD 90-100 & 239 & 8.98 & & G5 40-50 & 311 & 8.53 & $\mathrm{G}$ \\
\hline G17 90-100 & 405 & 10.6 & & GD $140-150$ & 238 & 7.55 & & G5 90-100 & 275 & 8.91 & \\
\hline G18 40-50 & 401 & 12.4 & G & G3 92-102 & 222 & 7.56 & $\mathrm{G}$ & G5 140-150 & 263 & 7.90 & \\
\hline G18 90-100 & 334 & 11.8 & & G3 140-150 & 292 & 7.29 & & G5 190-200 & 269 & 8.31 & \\
\hline G21 40-50 & 406 & 10.6 & $\mathrm{G}$ & G4 90-100 & 233 & 5.45 & G & G7 40-50 & 267 & 8.23 & $\mathrm{G}$ \\
\hline G21 90-100 & 466 & 11.0 & & G21 40-50 & 245 & 6.83 & G & G7 90-100 & 355 & 8.95 & \\
\hline G23 40-50 & 490 & 13.7 & $\mathrm{G}$ & G21 90-100 & 252 & 5.93 & & G8 40-50 & 252 & 7.87 & $\mathrm{G}$ \\
\hline G23 90-100 & 345 & 11.2 & & G21 140-150 & 220 & 6.91 & & G8 90-100 & 231 & 8.12 & \\
\hline G24 40-50 & 340 & - & G & G69 40-50 & 272 & 8.33 & G & G9 40-50 & 286 & 8.31 & G \\
\hline G24 90-100 & 366 & 12.8 & & G69 90-100 & 239 & 7.45 & & G9 90-100 & 20.7 & 1.64 & \\
\hline G27 40-50 & 426 & 13.6 & G & G70 90-100 & 314 & 7.47 & G & G9 137-147 & 242 & 6.98 & \\
\hline G27 90-100 & 446 & 13.6 & & G72 40-50 & 232 & 7.09 & $\mathrm{G}$ & G10 40-50 & 250 & 8.23 & G \\
\hline G30 40-50 & 370 & 12.8 & G & G72 90-100 & 236 & 6.67 & & G10 90-100 & 277 & 8.88 & \\
\hline G30 90-100 & 438 & 12.8 & & G73 40-50 & 235 & 7.16 & G & G17 40-50 & 231 & 10.3 & G \\
\hline G31 40-50 & 408 & 8.25 & G & G81 40-50 & 236 & 6.55 & G & G18 40-50 & 297 & 8.25 & G \\
\hline G46 40-50 & 504 & 12.0 & G & G81 90-100 & 246 & - & & G26 40-50 & 263 & 8.21 & G \\
\hline G47 40-50 & 415 & 12.1 & $\mathrm{G}$ & G82 40-50 & 173 & 21.6 & G & G26 90-100 & 241 & 8.90 & \\
\hline G47 90-100 & 366 & 12.0 & & G82 90-100 & 245 & 7.71 & & G26 140-150 & 233 & 8.57 & \\
\hline G49 40-50 & 486 & 12.0 & G & G85 40-50 & 233 & 6.67 & $\mathrm{G}$ & G27 40-50 & 266 & 8.42 & G \\
\hline \multirow[t]{29}{*}{ G50 40-50 } & 404 & 14.4 & G & G85 90-100 & 239 & 7.35 & & G27 90-100 & 303 & 7.89 & \\
\hline & & & & G85 140-149 & 272 & 8.18 & & G28 40-50 & 288 & 8.23 & G \\
\hline & & & & G86 40-50 & 239 & 5.08 & G & G28 90-100 & 239 & 8.07 & \\
\hline & & & & G86 87-97 & 152 & 4.49 & & G28 140-150 & 261 & 8.32 & \\
\hline & & & & G87 40-50 & 253 & 7.50 & G & G31 40-50 & 255 & 8.28 & G \\
\hline & & & & G87 90-100 & 250 & 7.60 & & G31 90-100 & 270 & 7.99 & \\
\hline & & & & G88 40-50 & 288 & 9.23 & G & G33 40-50 & 241 & 8.41 & G \\
\hline & & & & G88 90-100 & 254 & 8.64 & & G36 40-50 & 359 & 8.60 & G \\
\hline & & & & G89 40-50 & 244 & 7.53 & G & G36 90-100 & 290 & 8.06 & \\
\hline & & & & G89 90-100 & 243 & 6.42 & & G96 34-43 & 1,277 & 8.05 & $\mathrm{P}$ \\
\hline & & & & G90 40-50 & 228 & 12.6 & G & G96 84-93 & 2,408 & 9.11 & \\
\hline & & & & G91 40-50 & 140 & 3.56 & $\mathrm{G}$ & G96 134-143 & 2,528 & 11.8 & \\
\hline & & & & G91 90-100 & 315 & 5.97 & & G96 184-193 & 4,008 & 25.9 & \\
\hline & & & & G94 40-50 & 236 & 6.43 & G & G96 234-243 & 12,677 & 38.7 & \\
\hline & & & & G95 40-50 & 186 & 5.53 & $\mathrm{G}$ & G96 284-293 & 36,255 & 30.2 & \\
\hline & & & & G95 90-100 & 265 & 5.62 & & G96 334-343 & 33,381 & 29.6 & \\
\hline & & & & G96 41-50 & 16,325 & 46.0 & G & G96 384-393 & 42,826 & 34.4 & \\
\hline & & & & G96 90-100 & 30,730 & 40.3 & & G96 434-443 & 40,585 & 31.2 & \\
\hline & & & & G99 40-50 & 233 & 9.12 & G & & & & \\
\hline & & & & G99 90-100 & 245 & 6.07 & & & & & \\
\hline & & & & G103 40-50 & 242 & 7.86 & $\mathrm{G}$ & & & & \\
\hline & & & & G103 90-100 & 304 & 7.88 & & & & & \\
\hline & & & & G103 140-150 & 266 & 6.50 & & & & & \\
\hline & & & & G105 40-50 & 233 & 7.31 & G & & & & \\
\hline & & & & G105 90-100 & 235 & 9.37 & & & & & \\
\hline & & & & G105 135-145 & 251 & 10.0 & & & & & \\
\hline & & & & G107 40-50 & 232 & 6.08 & $\mathrm{G}$ & & & & \\
\hline & & & & G109 38-48 & 244 & 7.78 & $\mathrm{G}$ & & & & \\
\hline & & & & G111 40-50 & 265 & 6.43 & $\mathrm{G}$ & & & & \\
\hline
\end{tabular}

Note $: \mathrm{G}=$ Gravity core; $\mathrm{P}=$ Piston Core . 
(a)
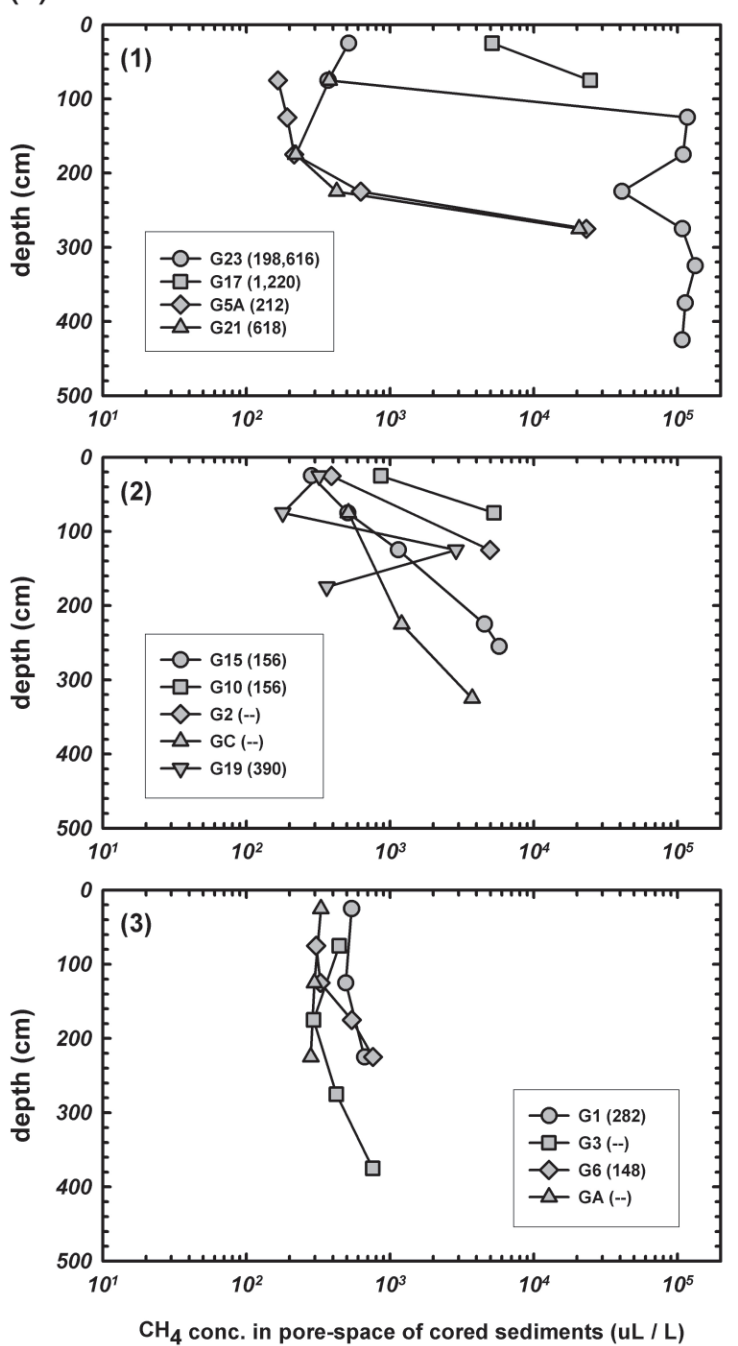

(b)


Fig. 3. Methane profiles of cored samples in this study. Figs. 3a and b (1): Methane concentrations are low in the shallower depth, which increases with increasing depth $\left(<10 \sim 10^{5} \mu \mathrm{L} \mathrm{L}^{-1}\right)$. Figs. $3 \mathrm{a}$ and $\mathrm{b}(2)$ : Methane profiles at some sites show a saw-tooth shape ( $>10^{4} \mu \mathrm{L} \mathrm{L}^{-1} ;<10 \mu \mathrm{L} \mathrm{L}^{-1}$ ). Figs. $3 \mathrm{a}$ and $b$ (3): Methane concentrations do not change much with depth and maintain similar values $\left(0 \sim 10^{3} \mu \mathrm{L} \mathrm{L}^{-1}\right)$. Note that $\mathrm{CH}_{4}$ concentrations have been converted from reported units $\left(\mu \mathrm{L} \mathrm{L}^{-1}\right)$. The number in parentheses represents the methane concentration $\left(\mathrm{nL} \mathrm{L}^{-1}\right)$ in bottom seawaters at that site. 
Geochemical profiles for cored samples are plotted in Fig. 4 with corresponding sulfate concentrations (Lin et al. 2006) in pore water and methane concentrations in pore space. According to the depths of the SMI, the profiles can be grouped into three categories as discussed below:

(a) No obvious sulfate reduction trend and no discernable SMI (Fig. 4a): The profiles show that methane concentrations are very low in pore spaces showing no changes with increasing depths and sulfates are not depleted. This may be due to two reasons: low methane fluxes, or the short length of cores. The sites where the depths of SMI cannot be determined are: G1, G2, G6, GA, GC, G10 of ORI-697, and G4, G11, G9, G24, N1, N2, N9, N11, N13 of ORI-718.

(b) There is obvious sulfate reduction trend, and depths of the SMI can be predicted at a few meters below the core length $(<\mathbf{1 0} \mathrm{m})$ (Fig. 4b): Profiles show that methane concentrations do not change with increasing depths. Only some stations contain higher methane concentrations in the bottom part of cored samples. Due to the short lengths of cored samples, the depths of the SMI cannot be measured. However, there might be higher methane fluxes in deeper sediments that affect the sulfate profiles with increasing depth. The curves of the sulfate profiles show a steep slope. Therefore, the depths of the SMI might be less than $10 \mathrm{~m}$ based on sulfate gradients, e.g., sites: G3, G15, G17, G19, G21 of ORI-697, and G14, N4 of ORI-718.

(c) The sulfate reduction trend is very sharp and the SMI appears at very shallow depths ( $<4$ m) (Fig. 4c): The profiles show that the depths of the SMI range between 100 and $400 \mathrm{~cm}$, e.g., G5A, G23 (the sudden decrease of methane concentration at $225 \mathrm{~cm}$ might be due to leakage or sampling problems such as the introduction of air during storage) of ORI-697; G22, N6, N8 of ORI-718, and G96 of ORI-732. Note that the methane and sulfate profiles of gas hydrate bearing sediments from Blake Ridge at Ocean Drilling Program (ODP) sites 994, 995, and 997 show that the depths of the SMI are around $20 \mathrm{~m}$ (Dickens 2001). Compared to the results of ODP 204 sites, the sites in this study present much shallower SMI depths, especially at sites G23 of ORI-697 and N8 of ORI-718 $(<100 \mathrm{~cm})$. The low methane concentrations $\left(\sim 10 \mathrm{~nL} \mathrm{~L}^{-1}\right)$ are controlled by AMO in the sulfate reduction zone. Below $100 \sim 300 \mathrm{~cm}$, methane concentrations can be up to $10^{4} \mathrm{~nL} \mathrm{~L}^{-1}$ and sulfate becomes totally depleted. To sum up, the stations shown in Figs. $4 \mathrm{~b}$ and $\mathrm{c}$ have very shallow depths of the SMI indicating that there should be very high methane fluxes below the sea floors in the region.

\subsection{Extremely High Methane Concentration}

In general, dissolved methane concentration in average seawater is very low, about $20 \mathrm{~nL} \mathrm{~L}^{-1}$. For example, in the Gulf of Mexico excluding areas where gas hydrate were found, methane concentration below $200 \mathrm{~m}$ is less than $50 \mathrm{~nL} \mathrm{~L}^{-1}$ except whenever methane is saturated due to bacterial activity or photochemical processes (Millero 1996). In the area offshore SW Taiwan, measured methane concentrations in core top water samples are higher than general seawater background values and vary from $10^{2}$ to $10^{5} \mathrm{~nL} \mathrm{~L}^{-1}$. Moreover, some extremely high methane 
(a)

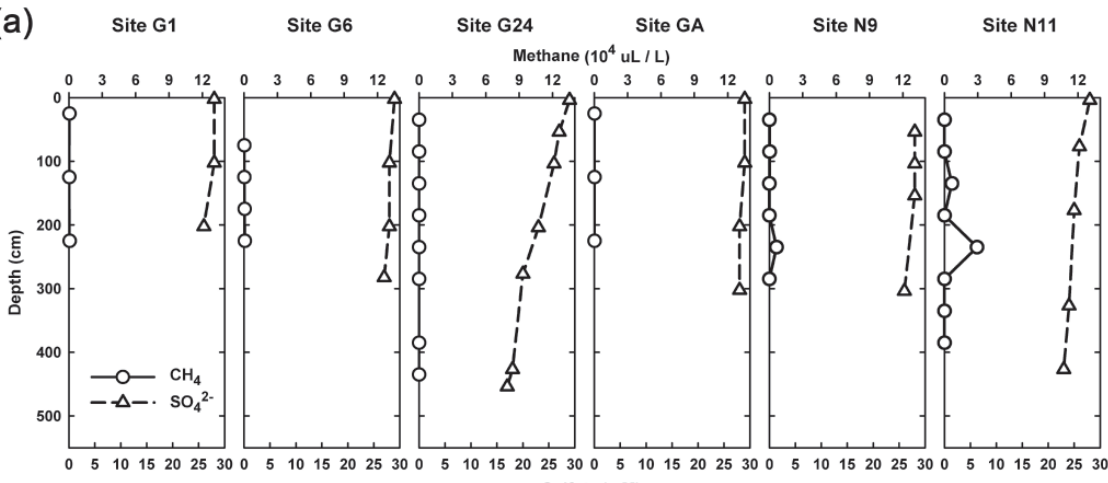

(b)

Site G3

Site G15

Site G17 Site G19 Site G21

Site N4
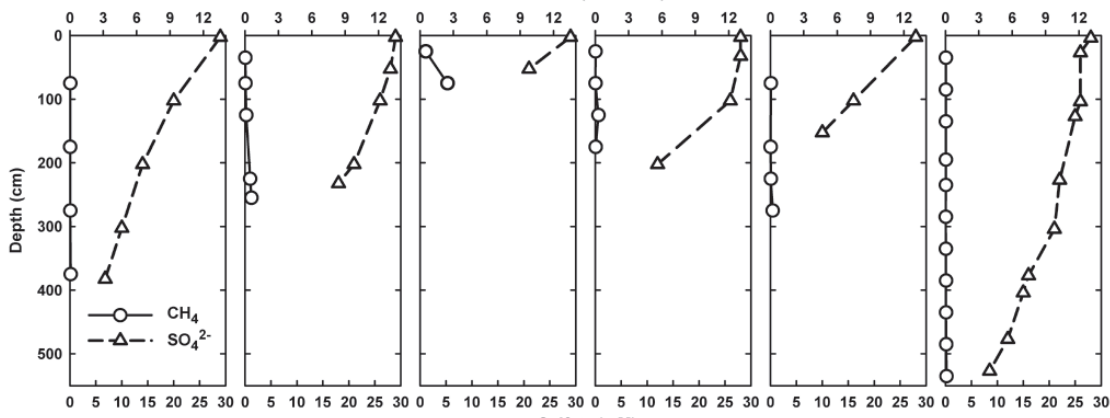

(c)

Site G5A

Site G22

Site G23

Site G96

Site $\mathbf{N 6}$

Site N8

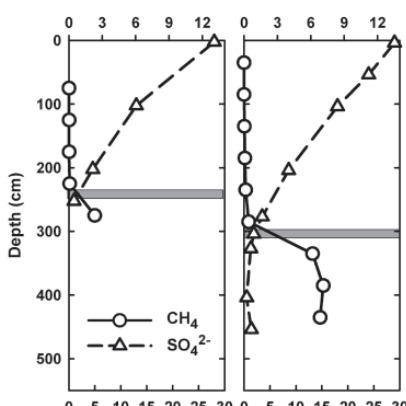

Methane $\left(10^{4} \mathrm{uL} / \mathrm{L}\right)$

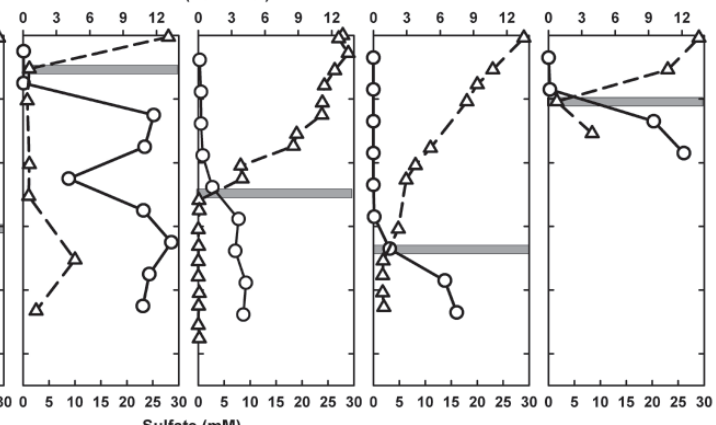

Sulfate (mM)

Fig. 4. Selected profiles of methane concentrations of pore space in cored samples and dissolved sulfate concentrations in pore water. (a) The depths of SMI cannot be determined because of the short length of cored samples; (b) The depths of SMI cannot be determined. According to the sulfate gradient, it can be predicted that the depths of SMI are very shallow $(<10 \mathrm{~m})$; (c) The depths of SMI can be determined and are very shallow $(<4 \mathrm{~m})$. The shadow in different profiles shows the possibility range of the depths of SMI. The data of sulfate concentrations are from Lin et al. (2006). 
concentrations ( $>100000 \mathrm{~nL} \mathrm{~L}^{-1}$ ) have been found in the study area, e.g., at sites $\mathrm{G} 23$ of ORI-697, N8 of ORI-718, and G96 of ORI-732. Furthermore, these values are even higher than the very high dissolved methane concentration in seawater columns of the Hydrate Ridge area (Suess et al. 1999). This indicates that there are active venting sources injecting methane into seawater in this area.

Based on the results of methane concentrations in the pore spaces of cored samples, there are extremely high methane concentrations at some sites, especially sites G23 of ORI-697, G22, N8 of ORI-718, and G96 of ORI-732. The highest methane concentration was detected at depths of $320-330 \mathrm{~cm}$ at site G23 of ORI-697 and its value is $133354\left(\mu \mathrm{L} \mathrm{L}^{-1}\right)$. This value is higher than that obtained at the gas hydrate and gas venting rich area of the Blake Ridge (Kvenvolden and Lorenson 2000; Lorenson and Collett 2000).

Generally, the value of dissolved methane concentration in bottom seawater indicates whether there is a gas source beneath the sea floor or not at that station and can be taken as an efficient method of investigating whether or not there is a methane vent on the sea floor. Comparing the results of dissolved methane concentrations in bottom seawater with methane concentrations of pore spaces in sediments (Table 1; Table 2; Fig. 2), there is good correlation at sites of ORI-697, i.e., the higher the dissolved methane concentration in bottom seawater, the higher the methane concentrations of pore spaces in cored samples and vise versa. However, no good correlations are found at other sites especially in ORII-1230 and ORI-732 cruises except sites G22, N8 of ORI-718, and G96 of ORI-732. Most of the stations contain high dissolved methane concentrations without unusually high methane concentrations in the pore spaces of cored samples $\left(\left[\mathrm{CH}_{4}\right]<400 \mu \mathrm{L} \mathrm{L}^{-1}\right)$.

The uncorrelated results of dissolved methane concentrations in bottom seawater and methane concentrations of pore space in sediments of ORII-120 and ORI-732 cruises might be caused by the water samples. As the bottom water samples are represented by gravity core top water samples, they might be disturbed by core top sediments. Therefore, methane in the pore spaces may have been released into the core top water, making the core top water rich in highly dissolved methane. Note that the methane concentrations of pore spaces are much higher than the dissolved methane concentrations in bottom water (up to 3 orders of magnitude). Although methane concentrations of pore spaces do not have unusually high values (presume $200 \mu \mathrm{L} \mathrm{L}^{-1}$ ), the dissolved methane concentrations can easily reach abnormally high values (200000 $\mathrm{nL} \mathrm{L}^{-1}$ ) after being disturbed by methane of the pore spaces. For this reason, the methane concentrations of pore spaces in core top sediments (the average depths range from $30-50 \mathrm{~cm}$ ) are treated as an indicator of methane vent on the seafloor (Table 3; Fig. 5).

Actually, the dissolved methane concentrations of core top seawater can not be used as the only indicator to estimate if there are methane vents on the seafloor. In order to study the unusual values at one station, dissolved methane concentrations at different depths of the water column (e.g., Chen and Tseng 2006; Yang et al. 2006) and methane concentration of pore spaces at different depths of cored samples need to be taken into consideration.

Dissolved methane concentrations in bottom water and methane concentrations of pore spaces in deeper sediments are extremely high at sites N8, G23 of ORI-697, G22 of ORI-718, and G96 of ORI-732. The depths of the SMI in these four sites are also very shallow. As mentioned before, the stations have very shallow SMI depths indicating that there might be 
Table 3. Comparison with dissolved methane in bottom waters and methane concentration of cored samples at the same site.

\begin{tabular}{|c|c|c|c|c|c|}
\hline ORI-697 & $\begin{array}{l}\text { pore space } \\
\mathrm{CH}_{4}(\mu \mathrm{L} / \mathrm{L})\end{array}$ & $\begin{array}{l}\text { bottom water } \\
\mathrm{CH}_{4}(\mathrm{~nL} / \mathrm{L})\end{array}$ & OR2-1230 & $\begin{array}{l}\text { pore space } \\
\mathrm{CH}_{4}(\mu \mathrm{L} / \mathrm{L})\end{array}$ & $\begin{array}{l}\text { bottom water } \\
\mathrm{CH}_{4}(\mathrm{~nL} / \mathrm{L})\end{array}$ \\
\hline G1 20-30 & $540(663)$ & 282 & GA $40-50$ & 241 & 19,733 \\
\hline G5A 70-80 & $166(22,251)$ & 212 & GD 40-50 & 240 & 4,897 \\
\hline G6 70-80 & $305(761)$ & 148 & G3 40-50 & 292 & 21,239 \\
\hline G10 20-30 & $864(5,283)$ & 156 & G21 40-50 & $245(252)$ & 53,888 \\
\hline G15 20-30 & $283(5,742)$ & 156 & G69 40-50 & 272 & 30,196 \\
\hline G17 20-30 & $5,145(24,699)$ & 1,221 & G73 40-50 & 235 & 11,035 \\
\hline G19 20-30 & $321(2,878)$ & 390 & G81 40-50 & $236(246)$ & 41,298 \\
\hline G21 70-80 & $378(452)$ & 613 & G82 40-50 & $173(245)$ & 65,153 \\
\hline G23 20-30 & $515(133,354)$ & 198,616 & G85 40-50 & $233(272)$ & 135 \\
\hline ORI-718 & & & G86 40-50 & 239 & 2,666 \\
\hline G4P $31-40$ & $375(745)$ & 3,740 & G87 40-50 & 253 & 20,633 \\
\hline G9B-P 31-40 & $867(3,668)$ & 4,970 & G89 40-50 & 244 & 58,259 \\
\hline G11B-P 31-40 & $384(1,138)$ & 3,638 & G90 40-50 & 228 & 100 \\
\hline G11C 31-40 & 392 & 822 & G91 40-50 & $140(315)$ & 44,383 \\
\hline G14 81-90 & $71(246)$ & 10,838 & G94 40-50 & 236 & 11,120 \\
\hline G22 31-40 & $35(68,490)$ & 78,731 & G95 40-50 & $186(265)$ & 36,844 \\
\hline G24 31-40 & $3(5)$ & 935 & G96 41-50 & $16,325(30,730)$ & 47,551 \\
\hline N1 31-40 & $7(2,024)$ & 6,204 & G99 40-50 & $233(245)$ & 18,732 \\
\hline N2 $81-90$ & 8 & 9,750 & G103 40-50 & $242(304)$ & 2,200 \\
\hline N4P $31-40$ & $377(938)$ & 3,793 & G105 40-50 & $233(251)$ & 988 \\
\hline N6 31-40 & $9(74,908)$ & 2,450 & G107 40-50 & 232 & 7,453 \\
\hline N8 $31-40$ & $117(121,716)$ & 613,268 & G109 38-48 & 244 & 475 \\
\hline N9 $31-40$ & $9(6,457)$ & 12,702 & G111 40-50 & 265 & 12 \\
\hline N11 31-40 & $7(29,261)$ & 10,544 & ORI-732 & & \\
\hline OR2-1207 & & & G1 40-50 & 256 & 5,365 \\
\hline G15 40-50 & $405(520)$ & 384 & G3 40-50 & 280 & 45,797 \\
\hline G16 40-50 & $346(360)$ & 441 & G4 40-50 & 288 & 5,494 \\
\hline G18 40-50 & 401 & 792 & G5 40-50 & 311 & 81,490 \\
\hline G24 40-50 & $340(366)$ & 723 & G7 40-50 & $267(355)$ & 8,667 \\
\hline G27 40-50 & $425(446)$ & 749 & G8 40-50 & 252 & 6,230 \\
\hline G30 40-50 & 370 & 458 & G9 40-50 & 286 & 64,117 \\
\hline G47 40-50 & 415 & 328 & G10 40-50 & $250(277)$ & 13,364 \\
\hline G50 40-50 & 404 & 597 & G17 40-50 & 231 & 53,796 \\
\hline ORI-732 & & & G18 40-50 & 297 & 21,471 \\
\hline G31 40-50 & $255(270)$ & 4,186 & G26 40-50 & 263 & 140 \\
\hline G33 40-50 & 241 & 8,751 & G27 40-50 & $266(303)$ & 44,743 \\
\hline G36 40-50 & 359 & 141 & G28 40-50 & 288 & 13,194 \\
\hline G96 34-43 & $1,277(42,826)$ & 536,323 & & & \\
\hline
\end{tabular}

Note: The number in parentheses represents the highest methane concentration of pore-spaces at that site. 


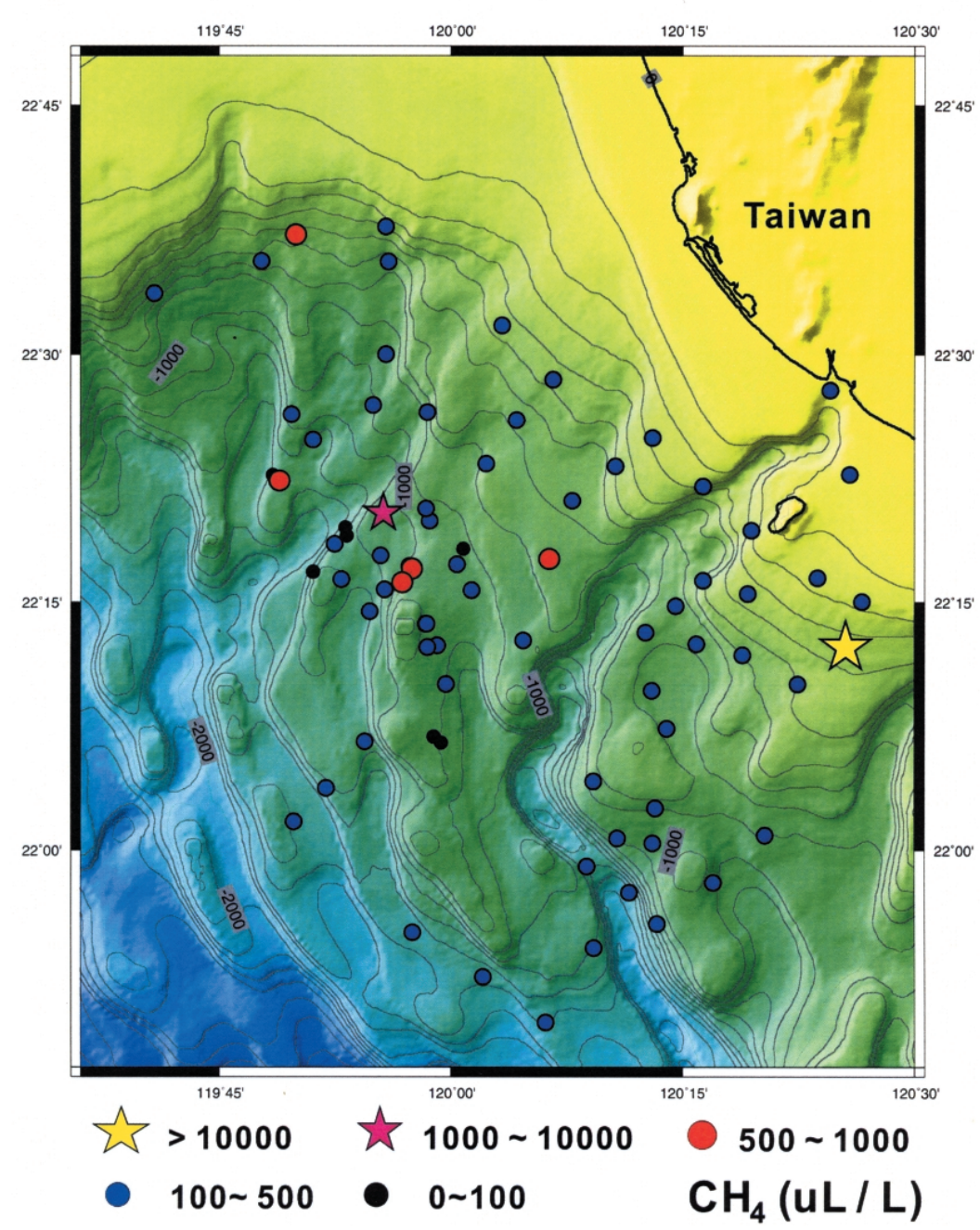

Fig. 5. Distribution of methane concentrations (in $\mu \mathrm{L} \mathrm{L}^{-1}$ ) of pore spaces in offshore southern Taiwan. Note that plotting methane concentrations from ORI-697 and ORI-718 are taken the data from upper $20 \sim 30 \mathrm{~m}$ sediments; while, those from ORII-1207, ORII-1230, and ORI-732 are from upper $40 \sim 50$ m sediment.

very high methane fluxes below the sea floor, which causes the extremely high methane concentrations at these four sites. Moreover, besides the intensive BSRs (Liu et al. 2006) and the very high methane fluxes, there are high sulfate reduction rates, authigenic carbonates and pyrites existing at sites N8, G23 of ORI-697, and G22 of ORI-718 (Huang et al. 2006; Horng et al. 
2006; Jiang et al. 2006; Lin et al. 2006). Therefore, beneath these sites, the upward migrating methane through shallow sediments into the seawater might be released from the dissociation of gas hydrates.

\section{CONCLUSIONS}

1. Sediments and bottom waters were systematically collected by piston cores and gravity cores during five cruises from 2003 to 2005 . The results show that many sites exhibit extremely high methane concentrations in both bottom water and sediments pore space compared to other gas hydrate areas in the world.

2. In general, the dissolved methane concentrations in bottom seawater are very high $(>1000$ $\left.n L^{-1}\right)$. Most values are much higher than the average seawater value $\left(<50 \mathrm{~nL} \mathrm{~L}^{-1}\right)$, especially at site $\mathrm{N} 8$ of ORI-718, where the value reaches $613268 \mathrm{~nL} \mathrm{~L}^{-1}$. This implies that a large amount of methane is venting from deep sediments up to the seawater in a wide area.

3. Methane is the main component of hydrocarbon gases in the study area, while ethane is the minor component and $\mathrm{C}_{3+}$ gases are usually below detection limits. Most of the cored sediments collected show a positive correlation of methane concentration in pore space with depth.

4. Methane concentrations at many sampling sites are higher than $100000 \mu \mathrm{L} \mathrm{L}^{-1}$, e.g., site $\mathrm{G} 23$ of ORI-697 and N8 of ORI-718. This infers that methane sources exist beneath the sea floor at these sites.

5. From methane and sulfate depth profiles, it has been found that the depths of the SMI are very shallow at many stations, which indicate the presence of very high methane fluxes. The high methane fluxes in this area might have been caused by the dissociation of gas hydrates below the sea floor. After gas hydrates dissociate, a large amount of methane is released and migrates upward to the shallow parts of sediment and the seawater. This can explain the unusually high methane concentration observed in this area.

Acknowledgements We thank the staff of Ocean Research Vessel I and II and all assistants and students for their assistance in collecting samples. Discussion with all PIs of this gas hydrate integrated project is helpful. Drs. Giuseppe Etiope, Chih-Hsien Sun, and Ulrich Knittel gave critical comments and improved the manuscript. Central Geological Survey of Taiwan, ROC financially supported this study (5226902000-06-93-02; 5226902000-05-94-02).

\section{REFERENCES}

Borowski, W. S., C. K. Paull, and W. Ussler, 1996: Marine pore-water sulfate profiles indicate in situ methane flux from underlying gas hydrate. Geology, 24, 655-658.

Borowski, W. S., C. K. Paull, and W. Ussler, 1999: Global and local variations of interstitial sulfate gradients in deep-water, continental margin sediments: Sensitivity to underlying methane and gas hydrates. Mar. Geol., 159, 131-154. 
Chen, C. T. A., and H. C. Tseng, 2006: Abnormally high $\mathrm{CH}_{4}$ concentrations in seawater at mid-depths on the continental slopes of the northern South China Sea. Terr. Atmos. Ocean. Sci., 17, 951-959.

Chi, W. C., D. L. Reed, C. S. Liu, and N. Lunberg, 1998: Distribution of the bottom simulating reflector in the offshore Taiwan collision zone. Terr. Atmos. Ocean. Sci., 9, 779-793.

Chiu, J. K., W. H. Tseng, and C. S. Liu, 2006: Distribution of gassy sediments and mud volcanoes offshore southwestern Taiwan. Terr. Atmos. Ocean. Sci., 17, 703-722.

Chow, J., J. S. Lee, R. Sun, C. S. Liu, and N. Lundberg, 2000: Characteristics of the bottom simulating reflectors near mud diapirs: offshore southwestern Taiwan. Geo-Mar. Lett., 20, 3-9.

Dickens, G. R., 2001: Sulfate profiles and barium fronts in sediment on the Blake Ridge: present and past methane fluxes through a large gas hydrate reservoir. Geochim. Cosmochim. Acta, 65, 529-543.

Horng, C. S., and K. H. Chen, 2006: Complicated magnetic mineral assemblages in marine sediments offshore of southwestern Taiwan: possible influence of methane flux on the early diagenetic process. Terr. Atmos. Ocean. Sci., 17, 1009-1026.

Huang, C. Y., C. W. Chien, M. Zhao, H. C. Li, and Y. Iizuka, 2006: Geological study of active cold seeps in the syn-collision accretionary prism Kaoping slope off SW Taiwan. Terr. Atmos. Ocean. Sci., 17, 679-702.

Jiang, W. T., J. C. Chen, B. J. Huang, C. J. Chen, Y. T. Lee, P. R. Huang, C. C. Lung, and S. W. Huang, 2006: Mineralogy and physical properties of cored sediments from the gas hydrate potential area of offshore southwestern Taiwan. Terr. Atmos. Ocean. Sci., 17, 981-1007.

Kvenvolden, K. A., 1998: A primer on the geological occurrence of gas hydrate. In: Henriet, J. P., and J. Mienert (Eds.), Gas Hydrates: Relevance to World Margin Stability and Climate Change, Geol. Soc. London, Spec. Publ., 137, 9-30.

Kvenvolden, K. A., and T. D. Lorenson, 2000: Methane and other hydrocarbon gases in sediment from the southeastern North American continental margin. In: Paull, C. K. et al. (Eds.), Proceedings of the Ocean Drilling Program, Scientific Results, 164, 29-36.

Lee, H. F., T. F. Yang, T. F. Lan, S. R. Song, and S. Tsao, 2005: Fumarolic gas composition of the Tatun Volcano Group, northern Taiwan. Terr. Atmos. Ocean. Sci., 16, 843-864.

Lin, S., W. C. Hsieh, Y. C. Lim, T. F. Yang, C. S. Liu, and Y. Wang, 2006: Methane migration and its influence on sulfate reduction in the Good Weather Ridge region, South China Sea continental margin sediments. Terr. Atmos. Ocean. Sci., 17, 883-902.

Liu, C. S., P. Schnürle, Y. Wang, S. H. Chung, S. C. Chen, and T. H. Hsiuan, 2006: Distribution and characters of gas hydrate offshore of southwestern Taiwan. Terr. Atmos. Ocean. Sci., 17, 615-644.

Lorenson, T. D., and T. S. Collett, 2000: Gas content and composition of gas hydrate from sediments of the southeastern North American continental margin. In: Paull, C. K. et al. (Eds.), Proceedings of the Ocean Drilling Program, Scientific Results, 164, 37-46.

Milkov, A. V., 2004: Global estimates of hydrate-bound gas in marine sediments: how much is really out there? Earth-Sci.Rev., 66, 183-197.

Millero, F. J., 1996: Chemical Oceanography. $2^{\text {nd }}$ Ed., CRC Press, Inc., Florida, 469 pp. 
Oung, J. N., C. Y. Lee, C. S. Lee, and C. L. Kuo, 2006: Geochemical study on hydrocarbon gases in seafloor sediments, southwestern offshore Taiwan - implications in the potential occurrence of gas hydrates. Terr. Atmos. Ocean. Sci., 17, 921-931.

Pecher, I. A., 2002: Gas hydrates on the brink. Nature, 420, 622-623.

Pellenbarg, R. E., M. D. Max, 2000: Introduction, physical properties, and natural occurrences of hydrate. In: Max, M. D. (Ed.), Natural Gas Hydrate in Oceanic and Permafrost Environments, Kuwer Academic, Netherlands, 1-8.

Schnürle, P., T. H. Hsiuan, and C. S. Liu, 1999: Constrains on free gas and gas hydrate bearing sediments from multi-channel seismic data, offshore southwestern Taiwan. Petrol. Geol. Taiwan, 33, 21-42.

Schnürle, P., T. H. Hsiuan, T. K. Wang, K. MacIntosh, C. S. Liu, D. Reed, and Y. Nakamura, 2002: Characteristics of gas hydrate and free gas offshore southwestern Taiwan: preliminary results from a combined seismic reflection/refraction analysis. Petrol. Geol. Taiwan, 35, 1-34.

Schnürle, P., C. S. Liu, and C. S. Lee, 2006: Acoustic and shear-wave velocities in hydratebearing sediments offshore southwestern Taiwan: tomography, converted waves analysis and reverse-time migration of OBS records. Terr. Atmos. Ocean. Sci., 17, 757-779.

Sloan, E. D. Jr., 1998: Physical/chemical properties of gas hydrates and application to world margin stability and climatic change. In: Henriet, J. P., and J. Mienert (Eds.), Gas Hydrates: Relevance to World Margin Stability and Climate Change, Geol. Soc., London, Spec. Publ., 137, 31-50.

Suess, E., M. E. Torres, G. Bohrmann, R. W. Collier, J. Greinert, P. Linkea, G. Rehder, A. Trehu, K. Wallmann, G. Winckler, and E. Zuleger, 1999: Gas hydrate destabilization: enhanced dewatering, benthic material turnover and large methane plumes at the Cascadia convergent margin. Earth Planet. Sci. Lett., 170, 1-15.

Wood, W. T., J. F. Gettrust, N. R. Chapman, G. D. Spence, and R. D. Hyndman, 2002: Decreased stability of methane hydrate in marine sediments owing to phase-boundary roughness. Nature, 420, 656-660.

Yang, T. F., C. Y. Chou, C. H. Chen, L. L. Chyi, and J. H. Jiang, 2003: Exhalation of radon and its carrier gases in SW Taiwan. Radiat. Meas., 36, 425-429.

Yang, T. F., G. H. Yeh, C. C. Fu, C. C. Wang, T. F. Lan, H. F. Lee, C. H. Chen, V. Walia, and Q. C. Sung, 2004: Composition and exhalation flux of gases from mud volcanoes in Taiwan. Environ. Geol., 46, 1003-1011.

Yang, T. F., P. C. Chuang, S. Lin, J. C. Chen, Y. Wang, and S. H. Chung, 2006: Methane venting in gas hydrate potential area offshore of SW Taiwan: evidence of gas analysis of water column samples. Terr. Atmos. Ocean. Sci., 17, 933-950.

Yeh, G. H., 2003: Geochemistry and sources of mud-volcano fluids in Taiwan. Master Thesis, Inst. Oceanogr., Natl. Taiwan Univ., 61 pp. (in Chinese)

Chuang, P. C., T. F. Yang, S. Lin, H. F. Lee, T. F. Lan, W. L. Hong, C. S. Liu, J. C. Chen, and Y. Wang, 2006: Extremely high methane concentration in bottom water and cored sediments from offshore southwestern Taiwan. Terr. Atmos. Ocean. Sci., 17, 903-920. 